\title{
PENGARUH MEDIA AUDIO VISUAL TERHADAP HASIL BELAJAR SISWA KELAS V SEKOLAH DASAR
}

\author{
Darda Abdullah Sjam ${ }^{1}$, Thia Maryati ${ }^{2}$ \\ 1,2Fakultas Keguruan IImu dan Pendidikan, Universitas Pasundan \\ 1darda.abdullah@gmail.com
}

\begin{abstract}
This research is motivated by problems in the field of recognizing low student learning outcomes, lack of utilization of facilities, infrastructure, and learning media, especially audio-visual media. The purpose of this study was to determine the effect of the use of audio visual media on learning outcomes of fifth grade students of SDN 066 Halimun. The method used in this study is a quantitative method of experimentation with a quasi experimental design type nonequivalent group design. Based on the results of research the data obtained from the implementation of research learning outcomes is proven by the average initial test pretest experimental class 60.65 increased in the number of posttest tests of 85.48 . While the average control class without using audio visual media or treatment got an average of learning outcomes of pretest 49.52 and posttest 58.55. The results of the statistical data analysis also proved that $\mathrm{Ha}$ was received from the $t$ test obtained thitung3,214> ttabel 2,045. It can be seen from the data above that the experimental class given action or audio-visual media has a positive effect on student learning outcomes in class $\mathrm{V}$.
\end{abstract}

Keywords: Learning Outcomes, Audio Visual Media, Influence.

\section{ABSTRAK}

Penelitian ini dilatar belakangi oleh adanya permasalahan dilapangan mengenal hasil belajar siswa yang rendah, kurangnya pemanfaatan sarana, prasarana,dan media pembelajaran khususnya media audio visual. Tujuan dari penelitian inipun untuk mengetahui pengaruh penggunaan media audio visual terhadap hasil belajar siswa kelas V SDN 066 Halimun. Metode yang digunakan dalam penelitian ini yaitu metode kuantitatif eksperimen dengan desain quasi experimental tipe nonequivalent group design. Berdasarkan hasil penelitian data yang diperoleh dari pelaksanaan penelitian hasil belajar yaitu terbukti dengan rata-rata tes awal kelas eksperimen pretest 60,65 meningkat pada jumlah tes posttest sebesar 85.48. Sedangkan rata-rata kelas kontrol yang tanpa menggunakan media audio visual atau perlakuan mendapat rata-rata hasil belajar sebesar pretest 49,52 dan posttest 58,55 . Hasil analisis data statistika pun membuktikan bahwa Ha diterima dari uji $\mathrm{t}$ diperoleh thitung3.214 > ttabel 2.045. Dapat diketahui dari data diatas bahwa kelas eksperimen yang diberikan tindakan atau media audio visual berpengaruh positif terhadap hasil belajar siswa kelas $\mathrm{V}$.

Kata Kunci: Hasil Belajar, Media Audio Visual, Pengaruh. 


\section{A. Latar Belakang}

Pendidikan adalah bagian terpenting yang harus dimiliki oleh setiap manusia. Baik dalam mendapatkan pengetahuan, pembelajaran, dan pengalaman secara formal maupun nonformal. Salah satunya adalah sekolah yang berperan sebagai pendidikan formal. Di dalam sekolah berlangsungnya proses belajar dan mengajar antara peserta didik dengan pendidik, dengan kata lain bahwa peserta didik sebagai individu yang belajar agar menjadi manusia dewasa yang sesuai dengan tujuan pendidikan nasional Indonesia. Oleh karena itu pendidikan disekolah mampu menjadikan peserta didik yang diharapkan dalam tujuan pendidikan nasional. Menurut undang-undang no. 20 tahun 2003 tentang Sisdiknas (Sistem Pendidikan Nasional) menyatakan bahwa "tujuan pendidikan nasional adalah mengembangkan potensi peserta didik agar menjadi manusia yang beriman dan bertaqwa kepada Tuhan Yang Maha Esa, berakhlak mulia, sehat, berilmu, cakap, kreatif, mandiri, dan menjadi warga negara yang demokratis, serta bertanggung jawab.

Tujuan pendidikan nasional tidak akan terealisasikan jika pembelajaran tidak di implementasikan pada setiap satuan pendidikan. Dan tujuan pendidikan pun tidak akan terealisasikan apabila dalam implementasinya tidak memperhatikan hal yang harus dipersiapkan dalam proses pembelajaran. Baik itu perencanaan pembelajaran, pengaturan ruang kelas, model pembelajaran atau bahkan media pembelajaran yang mendukung keberlangsungan pembelajaran.

Media menurut Djamarah dan Aswan (2013, hlm. 122) menyatakan bahwa "media adalah alat bantu dalam proses belajar mengajar yang digunakan pendidik untuk membelajarkan peserta didik demi tercapainya tujuan pengajaran". Maka dari itu media pembelajaran sangatlah penting bagi berlangsung nya pembelajaran. Dengan adanya penggunaan media pembelajaran materi yang disampaikan akan menjadi lebih konkrit. Dengan kata lain media pembelajaran merupakan alat bantu yang mampu memudahkan pendidik dalam menyampaikan informasi dan materi pembelajaran.

Dengan adanya perubahan zaman, kini pendidikan memasuki 
pada Pendidikan Abad 21. Menurut Djamarah (2013) ciri pendidikan abad 21 tersedianya informasi dimana saja dan kapan saja yang mampu menjangkau segala pekerjaan. Kemudian pembelajaran abad 21 lebih diarahkan pada learning to know, learning to do, learning to be, learning to life together. Dapat diartikan bahwa pembelajaran di abad 21 mengarahkan peserta didik untuk dapat belajar secara mandiri, mencari tau sendiri dengan bantuan bimbingan pendidik. Seiring dengan berkembang nya Ilmu Pengetahuan dan Teknologi (IPTEK) di abad 21 mengakibatkan kemajuan dalam pembelajaran. Para pendidik di abad 21 ini harus paham betul dan menguasai beragam macam media pembelajaran yang menunjang keberhasilan belajar peserta didik. Banyak media pembelajaran yang harus dikuasai diantaranya media audio visual. Mudah nya informasi yang mampu di dapat saat ini dan tersedianya beberapa sarana yang berada disekolah maka pembelajaran harus dirancang seefektif dan sekreatif mungkin untuk mempermudah pemahaman belajar peserta didik dalam menerima ilmu pengetahuan.
Dengan penggunaan media pembelajaran khususnya media audio visual diarahkan untuk mempermudah belajar peserta didik. Seperti disampaikan oleh Wati (2016, hlm. 4445) menyatakan bahwa "media audio visual adalah sebuah alat bantu yang digunakan dalam pembelajaran untuk membantu tulisan dan kata yang diucapkan dalam menyampaikan pengetahuan, sikap, dan ide dalam pembelajaran" . Kemudian dengan adanya penelitian ini yang di bantu oleh media audio visual diharapkan pembelajaran yang berbentuk abstrak akan menjadi konkrit dan akan merangsang rasa ingin tahu siswa. Dengan kata lain siswapun akan lebih aktif, semangat dalam mengikuti pembelajaran di kelas.

Teori belajar kognitif Piaget dalam Syamsu Yusuf (2013,hlm. 3) menyatakan bahwa "usia 6-11 tahun berada pada periode operasi konkrit yang mana anak sudah dapat membentuk operasi-operasi mental atas pengetahuan yang mereka miliki. Operasi ini memungkinkannya untuk dapat memecahkan masalah secara logis". Sehingga dengan dimudahkan nya pembelajaran, hasil belajar siswa pun akan menjadi meningkat. Kemudian hasil belajar siswapun 
Pendas : Jurnal IImiah Pendidikan Dasar, ISSN Cetak : 2477-2143 ISSN Online : 2548-6950 Volume IV Nomor 2, Desember 2019

diatas rata-rata KKM. Hal itu diharapkan pendidik untuk mengukur sejauh mana materi dikuasai oleh peserta didik.

Hasil Belajar Menurut Rusman (2015, hlm.67) menyatakan bahwa "kemampuan yang dimiliki siswa setelah ia menerima pengalaman belajar, dapat diartikan juga hasil belajar adalah sejumlah pengalaman yang diperoleh siswa yang mencakup beberapa ranah, diantanya ranah kognitif, afektif, dan psikomotor". Jadi dengan adanya hasil belajar mampu mengevaluasi pembelajaran yang sudah disampaikan kepada siswa. Hasil belajar merupakan bagian terpenting dalam pembelajaran. Guru akan mengukur sejauh mana siswa sudah menguasai materi yang disampaikan.

Hasil pengamatan saat magang kependidikan fenomena yang muncul di sekolah yaitu penggunaan media pembelajaran yang tidak memanfaatkan fasilitas dan lingkungan sekitar sekolah. Sudah tersedianya sarana dan prasarana yang telah diberikan pemerintah kota namun penggunaan media pembelajaran seperti audio visual tidak dimanfaatkan sebaik mungkin. Hal itu mengakibatkan pada saat materi disampaikan kurangnya pemahaman siswa dalam memahami materi pembelajaran yang kemudian mengakibatkan rendahnya hasil belajar siswa. Bukan hanya hasil belajar yang rendah, namun proses kegiatan pembelajaranpun kurang interaktif dan bervariasi. Maka dari itu diharapkan dengan adanya penggunaan media audio visual mampu menciptakan pembelajaran yang menyenangkan, interaktif , mampu meningkatkan hasil belajar siswa dan yang paling utama mampu menjadikan peserta didik yang memiliki pengetahuan dan wawasan lebih luas dalam mendapatkan pengetahuan dan pembelajaran.

Kemudian berdasarkan hasil pengamatan observasi dan wawancara dengan guru kelas V SDN Halimun Bandung. Selasa, 30 April 2019 terbukti bahwa pembelajaran di kelas cenderung bosan, tidak interaktif serta sulit untuk dipahami siswa jika dilakukan tanpa menggunakan media pembelajaran, Khususnya media audio visual. Nilai kriteria ketuntasan minimal (KKM) yang telah ditentukan guru adalah 70. Dan sebagian siswa kelas $\mathrm{V}$ seringkali tidak mengerti jika pembelajaran dibawakan tanpa menggunakan media pembelajaran. 
Pendas : Jurnal IImiah Pendidikan Dasar, ISSN Cetak : 2477-2143 ISSN Online : 2548-6950 Volume IV Nomor 2, Desember 2019

Yang mana guru kelas $\mathrm{V}$ menyatakan bahwa pembelajaran akan dikatakan berhasil jika sudah mencapai 75\%. Maka pembelajaran tersebut dikatakan lulus dan berhasil. Namun kenyataan nya pembelajaran dikelas jika tanpa menggunakan media pembelajaran khususnya audio visual hasil belajar siswa pun rendah dibawah KKM.

Menurut Nur Farida (2017) yang diperoleh berdasarkan dari hasil penelitian yang telah dilakukannya dengan judul skripsi Pengaruh Media Audio Visual terhadap Hasil Belajar IPS Siswa Kelas IV SD Dharma Karya UT menyatakan bahwa " hasil belajar peserta didik kelas eksperimen yang diajarkan menggunakan media audio visual lebih tinggi di banding hasil belajar peserta didik yang diajarkan menggunakan metode konvensional tanpa menggunakan media audio visual. Hal itu terbukti juga pada hasil nilai posttest thitung sebesar 5,220, sedangkan ttabel 2,000. Dengan kata lain thitung > ttabel, media audio visual berpengaruh positif." Kemudian dapat digambarkan berdasarkan dalam tabel dibawah ini bahwa penelitian nilai rata-rata pretest dan posttest hasil belajar yang dilakukan Nur
Farida (2017) berpengaruh positif dengan menggunakan audio visual: pada kelas eksperimen dengan nilai pretest 53,55 dan nilai posttest 85,32 , sedangkan pada kelas control untuk pretest sebesar 49,84, dan posttest sebesar 71,61.

Karena penggunaan media pembelajaran audio visual dapat mempermudah siswa belajar dalam upaya memahami materi pembelajaran sehingga siswa dapat mencapai target KKM yang diharapkan oleh sekolah. Dan diharapkan dengan adanya penelitian ini sebagai contoh dan menjadi pengetahuan baru baik bagi sekolah, siswa, pengajar, peneliti maupun pembaca untuk senantiasa memanfaatkan fasilitas,sarana, dan teknologi yang kini semakin meluas sehingga dapat bermanfaat bagi penelitian-penelitian selanjutnya untuk digunakan dilingkungan pendidikan formal maupun nonformal. Karena agar terciptanya proses pembelajaran yang efektif, efisien dan sesuai dengan Tujuan Pendidikan Nasional Republik Indonesia tidak hanya menggunakan satu media pembelajaran saja, akan tetapi dengan berkembangnya pengetahuan saat ini pendidik dituntut untuk kreatif 
Pendas : Jurnal IImiah Pendidikan Dasar, ISSN Cetak : 2477-2143 ISSN Online : 2548-6950 Volume IV Nomor 2, Desember 2019

dan inovatif dalam memanfaatkan beragam macam media yang ada dilingkungan sekitar kita. Serta mampu memanfaatkan fasilitas yang tersedia dilingkungan sekolah. Maka dari itu penulis akan melakukan penelitian sesuai dengan permasalahan dan harapan yang sudah dipaparkan diatas dengan judul penelitian "Pengaruh Media Audio Visual Terhadap Hasil Belajar Siswa Kelas V Sekolah Dasar". Diharapkan dengan media pembelajaran ini khususnya audio visual mampu meningkatkan hasil belajar siswa, minat dan semangat siswa untuk senantiasa belajar.

\section{B. Metode Penelitian}

Metode yang digunakan dan diambil dalam penelitian ini adalah metode kuantitatif eksperimen. Desain yang diambil dalam penelitian ini menggunakan desain

Quasi Experimental Design. Bentuk desain ini terdiri atas kelompok kontrol dan kelompok eksperimen, tetapi tidak dapat berfungsi sepenuhnya untuk mengontrol variabel-variabel luar yang mempengaruhi pelaksanaan eksperimen. Kemudian Tipe Desain ini yaitu Nonequivalent Control Group Design. Desain ini hampir sama dengan pretest-posttest control group design, hanya pada desain tipe ini kelompok eksperimen maupun kelompok kontrol tidak dipilih secara random dengan istilah lain pemilihan kelompok eksperimen dan kelompok kontrolnya dinamkaan dengan nama Sampling Purposive. Pada saat pelaksanaanya penulis membagi kelompok menjadi dua yaitu kelompok eksperimen yang diberikan perlakuan atau tindakan (media audio visual) dan kelompok kontrol yang tanpa penggunaan media audio visual (belajar tanpa menggunakan media audio visual).

Populasi dalam dalam penelitian ini adalah siswa-siswi kelas V SDN 066 Halimun Kota Bandung. Yang beralamat di Jl. Halimun No. 46, Lingkar Selatan, Kecamatan. Lengkong, Kota Bandung Provinsi. Jawa Barat. Kemudian objek populasi dalam penelitian ini adalah hasil belajar siswa-siswi kelas V SDN 066 Halimun Kota Bandung yang akan diujikan dan dilihat pengaruhnya dengan menggunakann media audio visual.

Sampel yang digunakan dalam penelitian ini yaitu siswa-siswi kelas VA dengan jumlah 31 orang dan kelas VB dengan jumlah 31 orang. Pada 
penelitian ini kelas VA sebagai kelompok eksperimen dan kelas VB sebagai kelompok kontrol. Pemilihan sampel penelitian ini tidak dilakukan pengacakan secara individu, karena tidak bisa mengubah kelas yang telah terbentuk sebelumnya. Kelas dipilih sebagaimana telah terbentuk tanpa campur tangan peneliti dan tidak dilakukannya pengacakan secara individu. Dikarenakan Desain Penelitian ini menggunakan Quasi Experimental Design jenis Nonequivalent Control Group Design. Maka desain tipe ini kelompok eksperimen maupun kelompok kontrol tidak dipilih secara random dengan kata lain teknik sampling purposive.

\section{Hasil Penelitian dan} Pembahasan

\section{Pengaruh Media Audiovisual} terhadap Hasil Belajar Siswa

Berdasarkan penelitian yang sudah dilaksanakan di kelas $\mathrm{V}$ A dan V B SDN 066 Halimun, peneliti mengumpulkan data hasil belajar siswa yang diambil dari tes pretest dan posttest belajar siswa dan dari hasil observasi pengamatan pada saat penggunaan media audio visual. Data menunjukan bahwa terbukti kelas yang menggunakan perlakuan atau menggunakan media audio visual saat belajar,mendapatkan nilai hasil belajar yang positif.

Dibuktikan dengan hasil nilai pretest kelas eksperimen yang kurang dari nilai rata-rata sekolah yaitu senilai 60,65 kemudian setelah diberikan perlakuan atau menggunakan media audio visual rata-rata nilai posstest hasil belajar siswa pun meningkat menjadi 85,48. Berbeda halnya dengan nilai hasil belajar siswa kelas kontrol yang pembelajarannya tanpa menggunakan media audio visual atau tanpa perlakuan. Rata-rata hasil pretest kelas kontrol senilai 49,50 dan rata-rata hasil posstest nya senilai 58,55 . Keduanya memiliki nilai yang rendah dibawah KKM yang sudah sekolah terapkan di SDN 066 Halimun. Karena nilai KKM yang diterapkan sekolah pada setiap mata pelajaran yaitu senilai 70 .

Hal ini dibuktikan dengan penelitian yang sudah sebelumnya dilakukan oleh Nur Farida (2017) dengan judul skripsi Pengaruh Media Audio Visual terhadap Hasil Belajar IPS Siswa Kelas IV SD Dharma Karya UT menyatakan bahwa "hasil belajar siswa kelas eksperimen yang diajarkan menggunakan media audio visual lebih tinggi di banding hasil 
belajar siswa yang diajarkan menggunakan metode konvensional tanpa menggunakan media audio visual. Dapat digambarkan dibawah ini bahwa hasil penelitian diketahui nilai rata-rata pretest dan posttest hasil belajar yang dilakukan Nur Farida berpengaruh positif dengan menggunakan audio visual. Kelas eksperimen pretest 53,55 dan posttest 85,35 . sedangkan kelas control pretest 49,84 dan posttest 71,61 . Hal itu menunjukan bahwa media audio visual mampu memberikan pengaruh positif terhadap hasil belajar siswa."

Setelah melewati beberapa tahap uji analisis statistik dapat diketahui pengaruh media audio visual terhadap hasil belajar siswa. Bukan hanya dapat dibuktikan dari hasil ratarata belajar siswa saja namun berikut uraian data hasil analisis statistik bahwa media audio visual berpengaruh positif dengan melalui uji hipotesis penelitian bertujuan untuk mengetahui apakah variabel $\mathrm{X}$ media audio visual ada pengaruh tehadap varibael $\mathrm{Y}$ hasil belajar. Sugiyono (2014, hlm. 257) menyatakan bahwa tingkat signifiksi yang digunakan yaitu $\alpha=0,05$ (5\%). Hipotesis yang akan diuji adalah:
$\mathrm{H}_{0}: \beta=0$ Artinya Media Audio Visal tidak berpengaruh signifikan terhadap Hasil Belajar.

$\mathrm{H}_{1}: \beta \neq 0$ Artinya Media Audio Visual berpengaruh signifikan terhadap Hasil Belajar.

Data yang diperoleh untuk menentukan uji hipotesisi ini dilihat pada hasil uji analisis statsitik regresi pada tabel coffiecients kolom $t$, Berdasarkan statistik uji $\mathrm{t}$ diperoleh nilai t hitung sebesar 3.214 , dimana nilai $t$ hitung tersebut akan dibandingkan dengan nilai t pada tabel distribusi t-student. Dengan $\alpha=0,05$, derajat bebas $(d b)=n-2=31-2=29$, untuk pengujian dua pihak diperoleh nilai t tabel sebesar \pm 2.045 . Dari uji t yang diperoleh sebesar thitung 3.214 > tabel 2.045 maka dapat diartikan bahwa media audio visual memiliki pengaruh positif .

$$
t_{\text {hitung }} \text { adalah }
$$

pengujian signifikansi untuk mengetahui pengaruh variabel $X$ terhadap variabel Y. Untuk mengetahui hasil signifikan atau tidak dilakukan pembandingan antara dengan dimana dicari pada signifikansi 0,05 pada uji dua sisi dengan derajat kebebasan (dk) n-2. Kriterianya yaitu $\mathrm{Ha}$ diterima jika $t_{\text {hitung }}>t_{\text {tabel }}$. Signifikansi adalah besarnya peluang untuk memperoleh 
kesalahan dalam mengambil keputusan dengan kriteria Ho ditolak jika signifikansi $<0,05$. Dan berdasarkan hasil data statistik yang sudah dilaksanakan dapat diketahui pada tabel cofficienst $t_{\text {hitung }}$ diperoleh sebesar 3.214 dan $t_{\text {tabel }}$ 2.045. Maka dinyatakan Ha diterima karena dari uji t diperoleh $t_{\text {hitung }} 3.214>t_{\text {tabel }} 2.045$. Artinya media audio visual berpengaruh terhadap hasil belajar siswa.

Hal ini sama halnya dengan penelitian terdahulu yang telah dilakukan Rafni Fajrianti (2017) dengan judul skripsi Pengaruh Media Audio Visual terhadap Hasil Belajar Siswa Dalam Sub Tema Perubahan Lingkungan Di Kelas V Min Bilui Aceh Besar menyatakan bahwa "hasil belajar siswa berdasarkan hasil pengujian hipotesis dengan menggunakan uji-t pada taraf kepercayaan 0.95 dan derajat kebebasan df $=39$ diperoleh tabel t0.95(53) $=1.684$ dan thitung $=1,83$. Maka thitung $\geq$ tabel atau $1,83 \geq 1.684$ artinya $\mathrm{Ha}$ diterima, Dapat disimpulkan bahwa terdapat pengaruh medua audio visual terhadap hasil belajar peserta didik dalam sub tema perubahan lingkungan di kelas V MIN Bilui Aceh Besar.
Selain itu berdasarkan penelitian Menurut Nur Farida (2017) yang diperoleh berdasarkan dari hasil penelitian yang telah dilakukannya dengan judul skripsi Pengaruh Media Audio Visual Terhadap Hasil Belajar IPS Siswa Kelas IV SD Dharma Karya UT menyatakan bahwa "hasil belajar peserta didik kelas eksperimen yang diajarkan menggunakan media audio visual lebih tinggi di banding hasil belajar peserta didik yang diajarkan menggunakan metode konvensional tanpa menggunakan media audio visual. Hal itu terbukti juga pada hasil nilai posttest thitung sebesar 5,220, sedangkan ttabel 2,000. Dengan kata lain thitung > ttabel, media audio visual berpengaruh positif. Hal ini menunjukkan bahwa, media audio visual lebih efektif diterapkan di kelas dibandingan media konvensional. Penggunaan media audio visual pada tahap orientasi pembelajaran akan sangat membantu keefektifan proses pembelajaran dan penyampaian pesan dan isi pembelajaran. Selain membangkitkan motivasi dan minat siswa, media pembelajaran juga dapat membantu siswa dalam meningkatkan pemahaman".

Berdasarkan data hasil analisis diatas telah dibuktikan maka variabel 
$X$ media audio visual berpengaruh positif terhadap variabel $Y$ hasil belajar. Hal itu dapat dilihat dari uji $\mathrm{t}$ diperoleh $t_{\text {hitung }} 3.214>t_{\text {tabel }} 2.045$. Kemudian dapat dilihat pada setiap nilai rata-rata kelas belajar siswa melebihi rata-rata dan KKM yang sudah sekolah tentukan. Berbeda halnya kelas yang tanpa menggunakan tindakan, rata-rata hasil belajarnya pun masih dibawah dari KKM yang sudah ditentukan sekolah.

\section{Aktivitas Guru dan Siswa}

\section{a. Aktivitas Guru}

Pada saat proses pembelajaran peserta didik merupakan subjek pembelajaran dan bukan objek pembelajaran. Oleh karena itu siswa harus berperan aktif dari pada pendidik. Pendidk hanyalah fasilitator, organisator, pengelola kelas, dan pembimbing peserta didik jika diperlukan.

Berdasarkan hasil observasi akivitas guru saat mengajar dikelas eksperimen menunjukan bahwa guru secara optimal memberikan pembelajaran kreatif, inovatif, dan interaktif. Guru pada saat pembelajaran hanyalah seorang fasilitator, pengelola kelas, dan pembimbing. Karena secara langsung peserta didik belajar dengan diberikannya sebuah perlakuan atau media audio visual pada saat pembelajaran.

Kemudian hasil observasi aktivitas guru saat mengajar dikelas kontrol guru lah yang lebih aktif dan menjadi subjek dalam pembelajaran. Beberapa siswa meminta guru untuk mengulas kembali materi yang sudah disampaikan. Guru pada saat dikelas kontrol merupakan subjek yang menjadi center pada saat pembelajaran. Materi pembelajaran yang harus di ulas kembali menjadikan siswa untuk bertanya dan bertanya kembali kedepan kelas.

\section{b. Aktivitas Siswa}

Berdasarkan hasil observasi yang dilakukan oleh peneliti. Selama proses pembelajaran dikelas eksperimen atau kelas yang diberikan perlakuan media audio visual sebagian besar semuanya siswa ikut berpartisifasi dengan pembelajaran. Dengan media audio visual siswa lebih fokus pada materi yang disampaikan lewat tampilan slide dan video edukatif. Secara langsung aktivitas siswapun kondusif dan sangat interaktif dengan adanaya materi yang menarik pada saat disampikan dan d sejumlah evaluasi 
Pendas : Jurnal IImiah Pendidikan Dasar, ISSN Cetak : 2477-2143 ISSN Online : 2548-6950

Volume IV Nomor 2, Desember 2019

yang disampaikan melalui media audio visual.

Dalam hal ini media audio visual berdampak positif pada pembelajaran yang dilakukan di kelas eksperimen. Nilai sikap peserta didiknya pun berpengaruh positif, dengan adanya media audio visual sikap kedisiplinan siswa didalam kelas sangat tinggi, hal itu dikarenakan antusias siswa yang tinggi untuk senantiasa menyimak materi yang disampaikan lewat media audio visual.

Dibuktikan dengan pendapat Sutrisno (2009, hlm. 54) menyatakan bahwa "media audio visual merupakan media perantara atau penggunaan materi dan penyerapan nya melalui pandangan dan pendengaran sehingga membangun kondisi yang dapat membuat siswa mampu memperoleh pengetahuan, keterampilan atau sikap". Hal itu dalam kenyataannya membuat sikap siswa secara langsung berubah menjadi disiplin, aktif, dan kreatif. Dengan disediakannya media audio visual bukan hanya antusias siswa saja, namun berakibat pada hasil belajar siswa yang berpengaruh positif dan meningkat dari pada sebelumnya yang tanpa menggunakan media audio visual.
Kemudian berdasarkan hasil observasi dan pengamatan pada saat dikelas kontrol, siswalah yang menjadi objek pembelajaran. Sebagian siswa hanya menerima saja pembelajaran, kemudian sikap perilaku kedisiplinan pun kurang terealisasikan dikelas ini. Materi yang dirasa menjenuhkan menjadikan siswa ingin mengakhiri pembelajaran yang sedang dibawakan oleh peneliti.

\section{Kesimpulan}

Berdasarkan hasil penelitian yang berjudul "Pengaruh Media Audio Visual terhadap Hasil Belajar Siswa Kelas V Sekolah Dasar" penulis dapat mengambil kesimpulan sebagai berikut:

Terdapat pengaruh media audio visual terhadap hasil belajar siswa kelas V SDN 066 Halimun. Hal ini terbukti dengan rata-rata tes awal kelas eksperimen pretest 60,65 meningkat pada jumlah tes posttest sebesar 2650 dan rata-rata setelah diberikan perlakuan atau media audio visual sebesar 85.48. Sedangkan rata-rata kelas kontrol yang tanpa menggunakan media audio visual atau perlakuan mendapat rata-rata hasil belajar sebesar pretest 49,52 dan posttest 58,55. Yang mana hal itu 
menjukan bahwa kelas eksperimen yang menggunakan media audio visual berpengaruh positif terhadap hasil belajar siswa. Karena rata-rata setiap mata pelajaran yang ditentukan di SDN 066 Halimun mencapai nilai 70, maka media audio visual terbukti berpengaruh positif. Hasil analisis data statistika pun membuktikan bahwa $\mathrm{Ha}$ diterima karena dari uji $\mathrm{t}$ diperoleh $t_{\text {hitung }} 3.214>t_{\text {tabel }} 2.045$. Artinya media audio visual berpengaruh terhadap hasil belajar siswa. Aktivitas Guru dan Siswa pada saat penelitian di SDN 066 Halimun berdampak positif pada kelas eksperimen yang menggunakan media audio visual atau tindakan. Pembelajaran yang dibawakan melalui media audio visual membuat guru berperan sebagai fasilitator, pengelola kelas, dan pembimbing. Sedangkan siswa lah yang berperan aktif pada saat pembelajaran. Kemudian dengan diberikannya perlakuan atau media audio visual dikelas eksperimen ini berdampak positif juga pada sikap siswa. Kedisiplinan, antusias, aktif, kreatif menjadi satu pada saat pembelajaran dilaksanakan. Siswa lah yang berperan sebagai subjek dalam pembelajaran. Siswa yang lebih banyak berperan aktif pada saat pembelajaran ketimbang guru. Maka dari itu media audio visual berpengaruh positif juga bagi aktifitas guru dan siswa.

\section{DAFTAR PUSTAKA}

Djamarah \& Aswan. (2013). Strategi Belajar Mengajar. Jakarta: Rineka Cipta.

Fajriati,Rafni.(2017). Pengaruh Media Audio Visual Terhadap Hasil Belajar Siswa dalam Subtema Perubahan Lingkungan di Kelas $\checkmark$ MIN Bilut Aceh Besar. Skripsi Program Studi PGMI UIN ArRaniri Darusalam Aceh Besar : diunduh 01 Meret 2019. Diterbitkan.

Farida,Nur.(2017). Pengaruh Penggunaan Media Audio Visual terhadap Hasil Belajar IPS Siswa Kelas IV di SD Dharma Karya UT. Skripsi Program Studi PGMI UIN Jakarta: diunduh 01 Maret 2019. Diterbitkan.

Rusman. (2014). Model-model Pembelajaran (Mengembangkan Profesionalisme. Depok : PT Raja Grafindo Persada

Sutrisno. (2009). Manajemen Sumber Daya Manusia. Yogyakarta: Prenada Media

Syamsu Yusuf. (2013). Psikologi Perkembangan Anak. Bandung: Remaja Rosdakarya

Wati, Ega Rima. (2016). Ragam Media Pembelajaran. Jakarta : Kata Pena. 